\title{
EDUKASI DAN PEMBUATAN SABUN CUCI TANGAN UNTUK MENCEGAH PENYEBARAN COVID-19 KEPADA MASYARAKAT KELURAHAN NAMU UKUR SELATAN KABUPATEN LANGKAT
}

\author{
Athaillah $^{1}$, Ratih Paramitha ${ }^{2}$ \\ ${ }^{1,2}$ Universitas Haji Sumatera Utara, Indonesia \\ Email: atha8237@gmail.com, mitha25.paramitha@gmail.com
}

\begin{abstract}
ABSTRAK
Sabun cuci piring merupakan alternatif sabun cuci tangan untuk mencegah penyebaran covid19. Tujuan kegiatan ini adalah untuk memberikan edukasi kepada masyarakat tentang bahan kimia yang digunakan sebagai bahan dasar sabun dan melakukan praktek tentang cara pembuatan sabun cair secara mandiri. Metode yang digunakan dalam kegiatan pengabdian kepada masyarakat ini adalah edukasi dan praktik pembuatan sabun pencuci piring. Hasil dari pelatihan ini adalah masyarakat mampu memproduksi sabun cair secara mandiri sehingga kebutuhan sabun cair sebagai sabun cuci tangan di masa covid-19 dapat terpenuhi dengan biaya yang lebih terjangkau.
\end{abstract}

Kata Kunci: Edukasi, Sabun cuci tangan, covid-19, Namu ukur selatan

\begin{abstract}
Dish soap is an alternative to hand soap to prevent the spread of COVID-19. The purpose of this activity is to provide education to the public about the chemicals used as the basic ingredients of soap and to practice how to make liquid soap independently. The method used in this program is education and practice of making dish soap. The result of this training is that the community is able to produce liquid soap independently so that the need for liquid soap as hand soap during the pandemic can be met at a more affordable cost.
\end{abstract}

Keywords: Education, hand washing soap, covid-19, Namu Ukur Selatan

\section{Pendahuluan}

Sabun adalah bahan yang digunakan untuk mencuci, baik pakaian, perabotan, badan, dan lain-lain yang terbuat dari campuran alkali, dan trigliserida dari lemak. Sabun dibuat secara kimia melalui reaksi saponifikasi atau disebut juga reaksi penyabunan. (Amalia et al., 2018). Dalam proses ini asam lemak akan terhidrolisa oleh basa membentuk gliserin dan sabun mentah. Sabun tersebut kemudian akan di olah lagi untuk menyempurnakannya hingga kemudian sampai ke pemakai (Pasir et al., 2014).

Sabun merupakan satu kebutuhan utama dalam upaya menjaga kebersihan dalam kehidupan sehari-hari termasuk dalam kebutuhan pokok, meskipun sabun tidak termasuk dalam kelompok kebutuhan primer. Kebutuhan akan sabun termasuk kedalam kebutuhan sekunder, karena kebutuhan primer yaitu sandang, pangan dan papan merupakan kebutuhan yang wajib untuk dipenuhi setiap hari. Kebutuhan sabun yang terus menerus 
setiap harinya, menyebabkan terjadinya kenaikan biaya kebutuhan (Amalia et al., 2018).

Di masa pandemic covid-19 sekarang, menjaga kebersihan tangan adalah salah satu upaya pencegahan penularan covid-19. Kebersihan tangan dapat dijaga dengan cara rutin mencuci tangan menggunakan sabun. Sabun cuci piring merupakan salah satu alternatif untuk mencuci tangan. Kemampuan menghilangkan kuman dari sabun cuci piring ini sering dimanfaatkan masyarakat untuk mencuci tangan di masa pandemi yang berguna untuk mencegah penyebaran covid-19 karena cuci tangan dapat membantu mencegah paparan kuman, bakteri, virus penyebab penyakit termasuk virus corona (Saputra, 2020). Hal ini menyebabkan kebutuhan sabun cuci tangan meningkat, sehingga pembuatan sabun cuci tangan secara mandiri sangat diperlukan oleh masyarakat.

Kurangnya pengetahuan masyarakat desa terhadap bahan kimia dan cara pengolahannya telah membuat tertutupnya peluang masyarakat memproduksi sabun cuci piring secara mandiri. Oleh sebab itu, diperlukan kegiatan tentang cara mengolah bahan kimia tersebut menjadi suatu produk sabun yang aman terhadap lingkungan dan sabun yang dihasilkan dari satu paket kecil bahan baku adalah berliter-liter sabun cair. Sehingga produk sabun yang dihasilkan dapat memenuhi kebutuhan penggunaan sabun sehari-hari (Pasir et al., 2014). Selain itu sabun ini juga dapat digunakan sebagai bahan cuci tangan guna mencegah penularan Covid-19 di daerah tersebut.

Tujuan dari kegiatan edukasi dan pembuatan sabun cuci tangan di Keluarhan Namu Ukur Selatan, Kabupaten Langkat adalah sebagai edukasi kepada masyarakat tentang bahan kimia dalam pembuatan sabun cuci tangan dan juga pentingnya menjaga kebersihan tangan pada masa pandemi Covid-19 sebagai upaya pencegahan penyebaran virus. Selain itu sabun cair ini juga dapat dimanfaatkan sebagai kebutuhan dalam kehidupan sehari-hari.

\section{Metode}

Metode yang digunakan dalam kegiatan pengabdian kepada masyarakat ini adalah edukasi dan praktik pembuatan sabun pencuci piring. Diskusi dan paparan dilakukan untuk memberikan edukasi kepada masyarakat terkait bahan kimia yang digunakan dalam pembuatan sabun cair. Metode pelatihan dilakukan dengan praktik atau demonstrasi pembuatan sabun pencuci piring. Metode praktik ini bertujuan agar masyarakat lebih mudah memahami dan mengingat proses pembuatannya serta mampu membuat secara mandiri.

Bahan-bahan pembuatan sabun dapat dengan mudah ditemukan di toko kimia terdekat. Bahan dasar pembuatan sabun cair adalah surfaktan dan garam serta bahan aditif lainnya seperti pelembab, parfum, pengawet dan zat pewarna.

\section{Hasil dan Pembahasan}

Sabun adalah surfaktan yang digunakan dengan air untuk mencuci dan membersihkan. Surfaktan juga berfungsi sebagai zat antimikroba dengan mekanisme menghambat kinerja bakteri saat adsorpsi (Setiawati et al., 2019). Jenis sabun yang sering digunakan adalah sabun cair. Sabun cair sering digunakan masyarakat untuk membersihkan peralatan makan dan peralatan dapur lainnya. Hal ini dikarenakan sabun cair diketahui 
memiliki kemampuan khusus untuk menghilangkan noda lemak, kuman dan juga sisa makanan dengan bersih.

Kemampuan menghilangkan kuman dari sabun cuci cair ini sering dimanfaatkan masyarakat untuk mencuci tangan di masa pandemi yang berguna untuk mencegah penyebaran covid-19. Untuk memenuhi kebutuhan sabun cair ini, dilakukan kegiatan edukasi dan pembuatan cuci tangan dapat membantu mencegah paparan kuman, bakteri, virus penyebab penyakit termasuk virus.

Edukasi yang disampaikan kepada masyarakat Namu Ukur Selatan dalam kegiatan ini adalah penjelasan tentang jenis bahan dan fungsinya untuk proses pembuatan sabun cair. Apalagi bahan yang digunakan adalah bahan kimia, kebanyakan masyarakat menggangap bahwa bahan kimia berbahaya dan harus dihindari. Padahal bahan tersebut sering digunakan dalam kehidupan sehari-hari seperti garam dan air. Oleh karena itu perlu dilakukan edukasi kepada masyarakat terkait peranan bahan kimia yang digunakan dalam proses sabun cair adalah aman dan ramah lingkungan.

Jenis bahan dan perannya dalam proses pembuatan sabun adalah sebagai berikut:

1. Surfaktan, berfungsi untuk membentuk busa dan mengangkat kotoran.

2. Garam, berperan sebagai bahan pengental. Semakin banyak garam yang ditambahkan dalam proses pembuatan sabun, maka sabun akan menjadi lebih kental.

3. Pelembab, menyerap air sehingga dapat melembutkan kulit dengan melindunginya dari kekeringan.

4. EDTA, sebagai pengawet dan pengikat logam sadah.

5. Pewangi, sebagai pemberi aroma tertentu sesuai dengan selera.

6. Zat warna, penghasil warna pada sabun sesuai dengan warna yang diinginkan

7. Pelarut, berfungsi melarutkan zat lain tanpa mengalami perubahan kimia (Arwati \& Anggraini, 2016).

Adapun bahan kimia yang digunakan dalam proses pembuatan sabun cair dijelaskan pada tabel 1 .

Tabel 1. Bahan pembuatan sabun cair

\begin{tabular}{llll}
\hline Nama Bahan & Jenis Bahan & Kuantitas & Satuan \\
\hline Texapon N70 & Surfaktan & 1 & $\mathrm{Kg}$ \\
Natrium Sulfat & Garam & 0,5 & $\mathrm{Kg}$ \\
Natrium klorida & Garam & 1 & $\mathrm{Kg}$ \\
Gliserol & Pelembab & 200 & $\mathrm{~mL}$ \\
EDTA & Pengawet & 15 & Gram \\
Pewangi & Pewangi & 100 & $\mathrm{~mL}$ \\
\hline Pewarna & Zat warna & 5 & Gram \\
\hline Air & Pelarut & 15 & $\mathrm{~L}$ \\
\hline
\end{tabular}

Pada Tabel 1 menjelaskan bahan utama dalam pembuatan sabun cuci. Bahan-bahan tersebut merupakan bahan yang mudah dijumpai oleh masyarakat dan juga bersifat aman dan ramah lingkungan. Dari bahan tersebut, surfaktan dan garam merupakan bahan utama dalam proses pembuatan sabun cair. Adapun surfaktan yang digunakan adalah texapon n70 atau sodium lauril sulfat merupakan bahan dasar sabun yang berfungsi mengangkat lemak dan kotoran, kemudian garam yang digunakan adalah natrium sulfat dan natrium klorida 
sebagai bahan pengental sabun. Untuk bahan lain sebagai bahan tambahan atau pendukung seperti pelembab, pengawet, pewarna dan pewangi. Untuk gambaran bahan pembuatan sabun cair yang digunakan dalam kegiatan ini dapat dilihat pada Gambar 1.

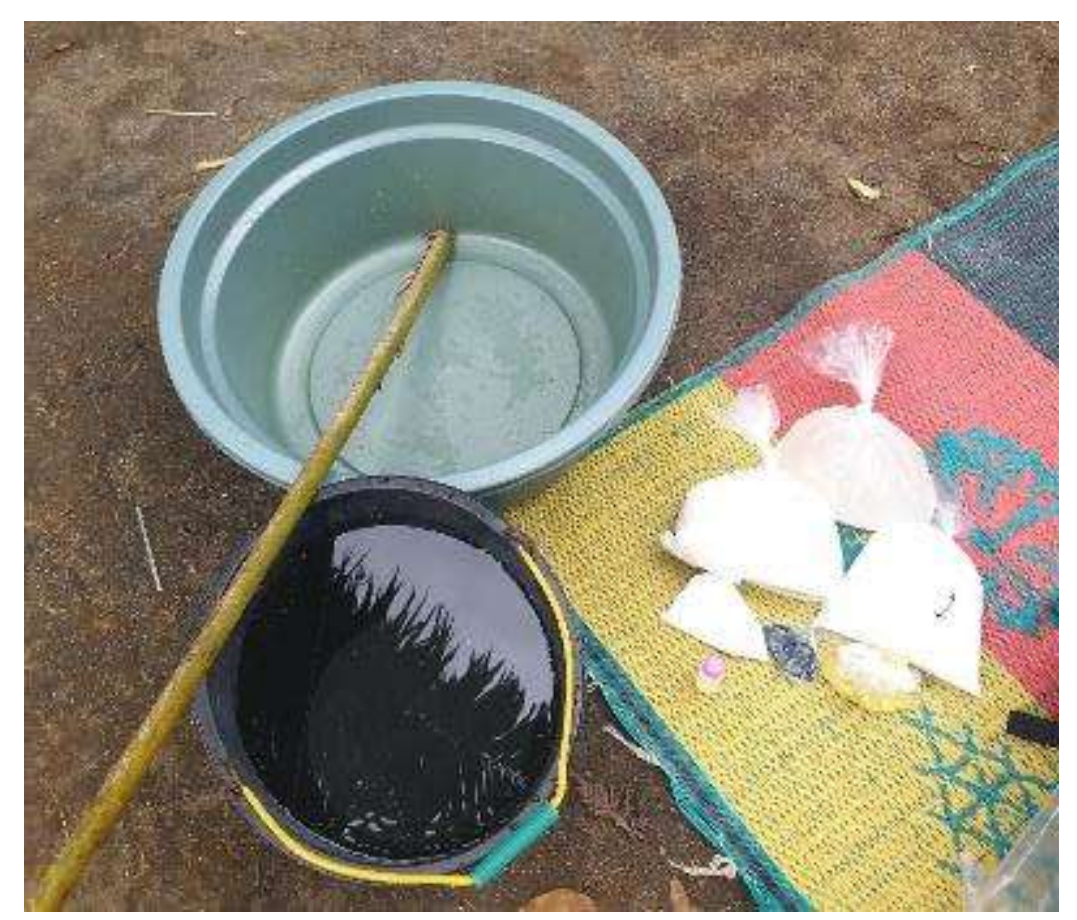

Gambar 1. Bahan pembuatan sabun cair

Setelah selesai dilakukan proses edukasi, selanjutnya dilakukan proses pembuatan sabun cair berdasarkan formula yang ada pada Tabel 1. Adapun proses pembuatan sabun cair adalah sebagai berikut.

1. Dimasukkan Texapon sebanyak $1 \mathrm{Kg}$ kedalam ember A, dan dilarutkan dengan 6 Liter air hangat sambil di aduk

2. Ke dalam ember B, dimasukkan Natrium sulfat sebanyak $0,5 \mathrm{Kg}$ dan Natrium Klorida sebanyak $1 \mathrm{Kg}$ dan dilarutkan dengan 6 Liter air.

3. Dicampurkan larutan Natrium sulfat dan Natrium Klorida yang telah dilarutkan dalam ember B ke dalam larutan Texapon yang ada dalam ember A sedikit demi sedikit sambal diaduk.

4. Tambahkan Pewangi, pengawet, pelembab dan pewarna, lalu aduk sampai merata

5. Tambahkan air sebagai pelarut 14 liter agar sabun menjadi lebih encer dan mudah dimasukkan kedalam wadah botol.

6. Langkah terakhir adalah didiamkan larutan sabun tersebut selama 1 hari sampai busa menghilang.

Proses pembuatan sabun cair ini dapat dilihat pada Gambar 2. Dari gambar tersebut dapat dilihat bahwa dalam 1 paket sabun cuci dapat menghasilkan sabun 1 ember atau sekitar 20 Liter. Hal ini sangat berguna bagi masyarakat untuk dapat membuat sabun secara mandiri, sehingga kebutuhan akan sabun untuk kehidupan sehari-hari dan juga untuk memenuhi kebutuhan mencuci tangan di wilayah tersebut dapat terpenuhi, sehingga upaya mencegah penyebaran Covid-19 di masa pandemi dengan cara mencuci tangan secara rutin 
dapat dijalankan.

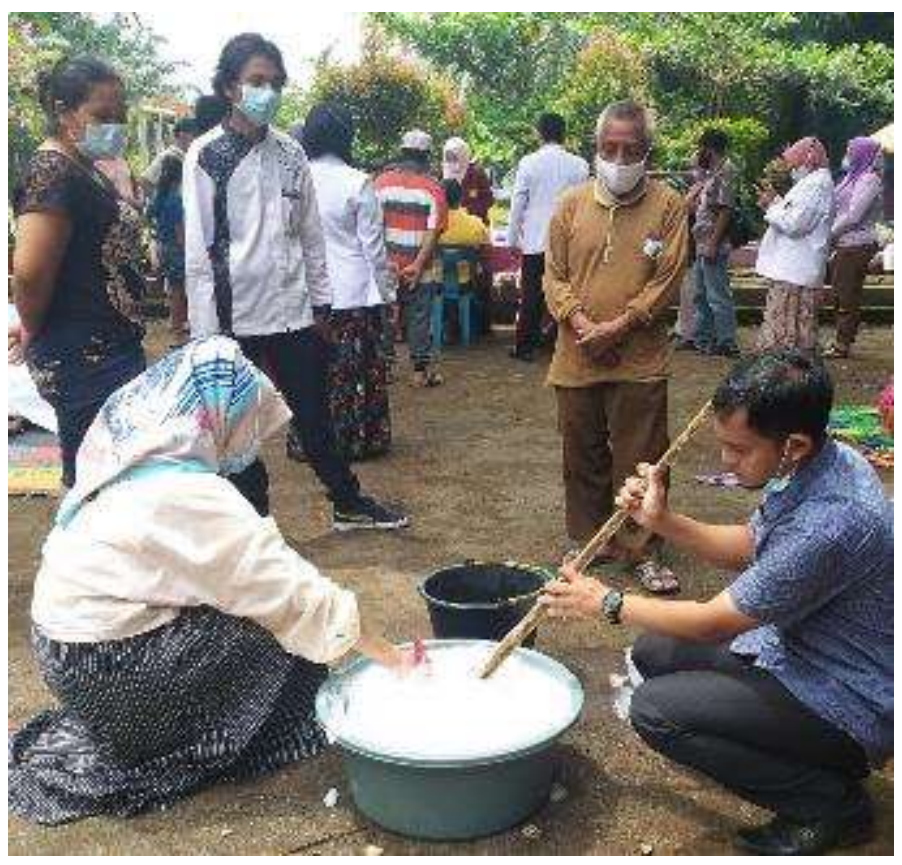

Gambar 2. Proses pembuatan sabun cair

Berdasarkan Gambar 3 dapat dilihat bahwa masyarakat Namu Ukur Selatan Kabupaten Langkat sangat antusias dan bersemangat dalam mengikuti kegiatan ini. Sehingga tujuan dilaksanakan kegiatan ini yaitu memberikan edukasi dan demonstrasi kepada masyarakat tentang cara pembutan sabun cair sebagai sabun cuci tangan di masa pandemi ini dapat terlaksana dengan baik. Selain itu, masyarakat menjadi mampu memproduksi sabun cair secara mandiri dan juga dapat mengurangi biaya yang harus dikeluarkan untuk memenuhi kebutuhan akan sabun cuci tangan. Sehingga upaya masyarakat dalam mencegah penularan penyebaran covid-19 dengan cara menjaga kebersihan tangan di wilayah tersebut dapat terlaksana dengan baik.

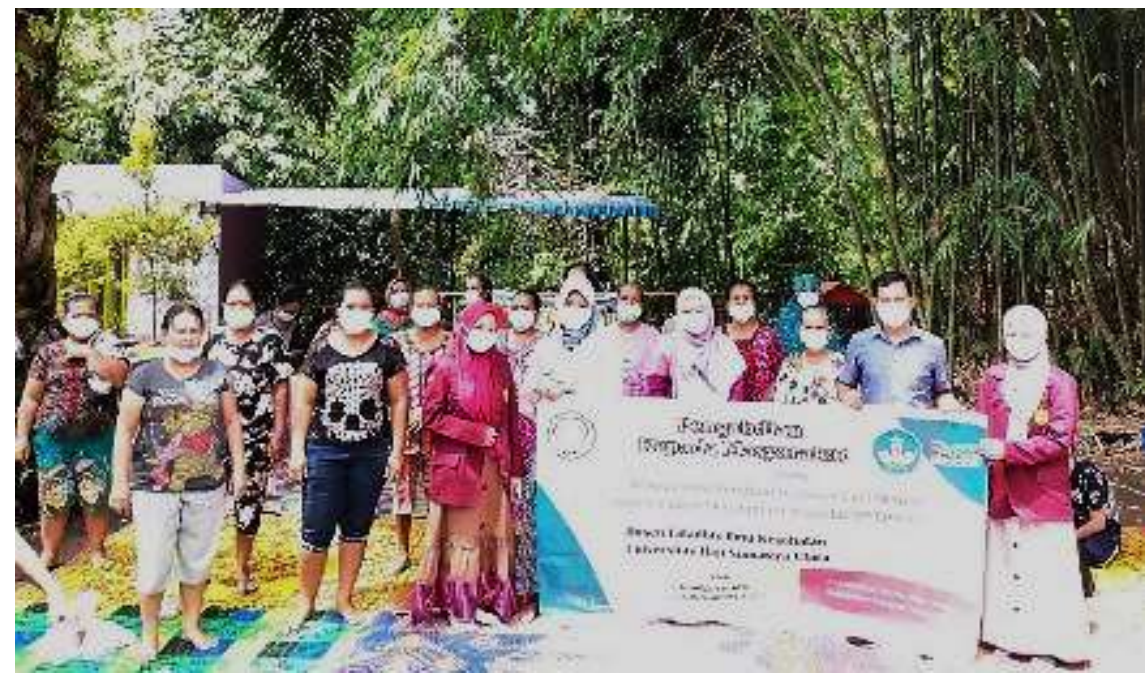




\section{Gambar 3. Foto Kegiatan PKM}

\section{Kesimpulan}

Kegiatan pengabdian kepada masyarakat berjalan dengan lancar sesuai dengan yang direncanakan. Kegiatan ini dapat meningkatkan pengetahuan dan ketrampilan dalam pembuatan sabun cair sebagai sabun cuci tangan sebai upaya pencegahan penularan Covid19.

\section{Referensi}

Amalia, R., Paramita, V., Kusumayanti, H., Wahyuningsih, W., Sembiring, M., \& Rani, D. E. (2018). Produksi Sabun Cuci Piring Sebagai Upaya Peningkatkan Efektivitas Dan Peluang Wirausaha. Metana, 14(1), 15. https://doi.org/10.14710/metana.v14i1.18657

Arwati, I. G. A., \& Anggraini, R. (2016). Penyuluhan Pembuatan Pencuci Piring Ramah Lingkungan di Wilayah Jakarta Barat. Jurnal Abdi Masyarakat (JAM), 2(1), 25-30.

Pasir, S., Pendidikan, J., Islam, A., Ilmu, F., Islam, A., Indonesia, U. I., Kimia, J. I., \& Islam, U. (2014). Penyuluhan dan praktik pembuatan sabun cuci piring cair 1. 3(3), $155-159$.

Saputra, A. (2020). Cuci Tangan Dengan Sabun Cuci Piring untuk Cegah Virus Corona COVID-19. https://health.grid.id/read/352063658/cuci-tangan-dengan-sabun-cucipiring-untuk-cegah-virus-corona-covid-19?page=all

Setiawati, I., Oktarina, E., \& Ariani, A. (2019). Kesesuaian mutu deterjen cuci air untuk alat dapur quality fits detergent of dishwashing liquid. Prosiding PPIS, 1, 135-142. https://ppis.bsn.go.id/downloads/2019/Kesesuaian Mutu Deterjen Cuci Cair untuk Alat Dapur.pdf 